\title{
ФЕНОМЕНОЛОГІЯ ПРОЕКТУВАННЯ НОВІТНІХ ОСВІТНІХ СИСТЕМ У ГЛОБАЛЬНОМУ ОСВІТНЬОМУ СЕРЕДОВИЩІ
}

У статті досліджується проблема конџептуалізації когнітивно-комунікативних та інформаційно-семіотичних вимірів проектування інноваційної моделі вищої освіти на світовому та вітчизняному рівні у науковому дискурсі XXI століття. Обгрунтовуються актуальність досліджуваної проблеми, методологічні засади проектування новітніх освітніх систем на основі синергетичного підхіду як методу аналізу педагогічних явищ; розглянуто інноваційні підходи до проектування освітніх моделей у контексті розуміння креативно-аналітичного системного прочесу відтворення досліджуваної діяльності.

Ключові слова: проектування; синергетичний підхід; освітні моделі; вища освіта.

Постановка проблеми. Актуальність проблеми проектування новітніх освітніх систем обумовлена соціальними і політичними умовами існування i розвитку суспільства у контексті глобальних інтеграційних процесів. Важливим i актуальним $є$ аналіз досліджень проектування сучасних освітніх моделей та інноваційних процесів у вищій школі. Значущість і доцільність дослідження зумовлена такими факторами: 1) перехід до ринкової економіки і необхідність соціального захисту трудящих ставлять перед освітою серйозні завдання; 2) пріоритетністю напрямів державної політики в контексті інтеграції вітчизняної вищої освіти до європейського та світового освітнього простору визначено те, що необхідною передумовою проектування інноваційної моделі вищої освіти $\epsilon$ докорінне оновлення освітньої системи, зокрема поліпшення іiі кадрового забезпечення, яке значною мірою залежить від здатності системи освіти готувати висококваліфікованих фахівців, які вміють пристосовуватися до постійних змін, що пов'язано із входженням України у світовий освітній простір.

Таким чином, за орієнтир береться те, що кожна особа зацікавлена в тому, щоб не лише найширше розкрилися іiі здібності та потенційні можливості, не тільки в тому, щоб здобути освіту, але й здатність пристосовуватися до нових політичних та соціально-економічних реалій сьогодення. Держава ж повинна дбати про задоволення цих потреб особистості, які 6 поєднувалися 3 піклуванням про потреби суспільства в цілому. Для цього необхідно орієнтуватися на теоретичну модель “інноваційної людини', яка випробувана у світі та зорієнтована на те, щоб прищеплювати випускникам вищої школи i глибокі, міцні знання, і гнучкість, і мобільність.

Аналіз досліджень і публікацій. Ступінь розуміння й усвідомлення трансформаційних процесів які відбуваються в національній та світових освітніх системах вищої освіти визначається ступенем усвідомлення окремих аспектів, до яких слід віднести уявлення людини про очікувані і фактичні результати, об'єктивні і суб'єктивні умови реалізації цілей, виконання або невиконання їх з точки зору зовнішніх і внутрішніх можливостей, розуміння 
відношення індивідуальних і суспільно значущих потреб, ступеня їхньої незбіжності або дивергенції, а також відношення цілей і потреб та мотивів [4]. Саме тому пріоритетне значення в умовах світових глобалізаційних процесів набуває проектування сучасних освітніх моделей на основі синергетичного підходу.

Нині змагання розвинених держав дедалі більше зміщується у бік змагання їхніх освітніх систем. Не можна не погодитися з думкою Сисоєвої С.О. про те, що “освітологічний аналіз видається особливо доцільним, коли мова йде про реформування й модернізацію освіти, оскільки означені процеси є відгуком на трансформації у дотичних до освіти суспільних сферах, що викликані у свою чергу об'єктивними змінами, до яких можна віднести цивілізаційні, транснаціональні та зміни в освіті на національному рівні” [цит. за 12].

Цікавими розвідками у сфері проектування інноваційних моделей вищої освіти є праці Альтбаха П., Андрющенко В.П., Дубасенюк О.А., Коваль Т.I., Кремень В.Г., Катеринчука О.В., Лузік Е.В., Лугового В.І., Пастернака П., Сисоєвої С.О. Хорта Г., Юнга I. та інших. Водночас, зазначена проблема не знайшла широкого висвітлення в концептуально-методологічних основах проектування новітніх освітніх систем.

Метою статті $\epsilon$ теоретичне обгрунтування алгоритму системного проектування моделі новітньої освітньої системи, яка розкриває сутність та особливості глобального освітнього середовища.

Виклад основного матеріалу. Системним, на нашу думку, є об'єкт будьякої природи (чи сукупність взаємодіючих об'єктів будь-якої, в тому числі і різної природи), що має “системні” властивості, тобто властивості, які не притаманні жодній частині системи при будь-якому способі поділу і які не випливають iз властивостей частин. Частини системи 3 аналогічними властивостями є підсистемами [7]. Поєднання кількох систем, які мають системні властивості, - це надсистема, або система вищого порядку. Елементом системи є об'єкт (частина системи) 3 однозначно виявленими відомими властивостями.

Система (підсистема, елемент) має входи та виходи: вхід - це дискретна чи неперервна множина контактів, через які вплив середовища передається системі; вихід - множина контактів, через які система впливає на середовище. Вплив може виявлятися у передачі речовини, енергії, інформації чи комбінації цих компонентів. Відповідно можна говорити про речовинний, енергетичний, інформаційний обмін між середовищем та системою (метаболізм).

Середовище - це оточення, 3 яким система взаємодіє. Системи, що взаємодіють із середовищем, називають “відкритими”. “Закриті” (“замкнені”) системи середовища не мають. Середовищем для однієї з підсистем системи можуть бути інші підсистеми чи частина 3 них, а також інші, "сторонні" системи [13]. Середовище також є системою.

Під станом системи розуміють упорядковану сукупність значень параметрів (внутрішніх та зовнішніх), які визначають хід процесів, що виникають у системі. Стан системи може бути кінцевим, зчисленним чи 
континуальним [11]. Є багато способів вичленування систем залежно від критерію, який задається і на основі якого розглядають реальну дійсність. Так, за субстанціональною основою та походженням системи поділяють на: реальні (об'єкти неживої, живої та соціальної природи); концептуальні, чи ідеальні (поняття, теорії, моделі); штучні (тобто створені людиною); мішані (в них можуть поєднуватися елементи природної, штучної та суспільної природи, наприклад, біотехнічні, соціотехнічні, біосоціальні системи і т. ін.) [18]. На практиці досить часто застосовують термін “велика” система. Під великою (великомасштабною) системою розуміють систему, кількість елементів якої дуже велика, а склад різнорідний [16].

Внаслідок різного ступеня змінності основних характеристик розрізняють статичні та динамічні системи Коли ж бажають підкреслити ступінь стійкості систем у певних заданих обмеженнях, виділяють стаціонарні і нестаціонарні (мобільні) системи. Розглянемо постановку завдання синтезу складних логікопедагогічних систем. Наукова практика, спрямована на створення новітніх освітніх систем (нових ідей, нових технологій навчання, нових відносин), починається 3 аналізу ситуації і є “авангардом”, “головні сили” - це синтез, творчість, перетворення існуючого і створення нового [9]. Проаналізувавши існуючі та перспективні методи синтезу систем, застосуємо таку структуру викладення: спочатку проаналізуємо неформальні методи синтезу, потім опишемо існуючі кількісні методи, сформулюємо проблему (необхідність нового, нетрадиційного підходу) і намітимо шлях іiі розв'язання. Розглянемо неформальний синтез складних систем. Було б невиправданим спрощенням вважати неформальний (тобто неформалізований, такий, що не включає апарат кількісного дослідження) метод синтезу систем якимось попереднім, підготовчим етапом аналізу. Справді, наука досягає досконалості, коли вона асимілює не тільки методи кількісного аналізу, а й методи неформального дослідження, які мають часом велике евристичне значення [14]. При цьому неформальні методи можна умовно поділити на переважно логічні та такі, які використовують інтуїцію. Як завжди, найбільшу ефективність має поєднання їх, система логічних (у широкому розумінні) та евристичних прийомів. Таке поєднання локалізує слабкі сторони кожного підходу і реалізує їхню силу. Так, кількісні обгрунтування е статичними і загальними, але математика виявляє неспроможність, коли вона стикається зі складністю і нелінійністю реальних ситуацій. Евристика, вільно оперуючи нечіткими поняттями, зриває 3 дерева пізнання надзвичайні плоди, але творчість є елітарною і важко керованою.

Методи розроблення творчих рішень - одна з галузей сучасної науки, що бурхливо розвивається. Серед ii творців визначну роль відіграли практики організатори роботи творчих колективів (А.Осборн, У.Гордон, Г.С.Альтшуллер), психологи (Е. де Бонне, Ж.Адамар, З.Фрейд), математики (Р.Декарт, Н.Вінер, Д.Пойа) і філософи (К.Полпер, І.Б.Новік, Ю.А.Шрейдер).

Усвідомлено спрощуючи, поділимо методи неформального синтезу систем на: а) суто логічні; б) такі, що грунтуються переважно на інтуїції та судженнях; 
в) комбіновані (системні). Суто логічний синтез використовувався в історії людства як метод спроб і помилок.

Процес проектування послідовно проходить три стадії: аналітичну, оперативну та синтетичну. Аналітична стадія: поставити завдання; подати ідеальний варіант вирішення; знайти суперечність; установити іiі причину; визначити умови, за яких усуваються суперечності. Оперативна стадія за тлумаченням Євтодюка А.В.: перевірити, чи можна щось змінити в самій системі [6].

Аналізуючи викладене вище, розкриємо наш задум щодо методології проектування моделі вищої освіти. Проектування новітніх освітніх моделей це багатостадійний (багатоетапний) динамічний процес, тобто процес відображений в часі, а освітня система, його реалізуюча - динамічна система. 3 синергетичної точки зору, - це алгоритм послідовних взаємозалежних дій всіх учасників освітнього процесу у контексті певних умов, що забезпечує досягнення поставленої освітньої мети. Теоретичному обгрунтуванню спроектованої моделі новітньої освітньої системи, як складного багатопланового процесу, сприяв синергетичний підхід як метод аналізу педагогічних явищ, що розглядається нами, як напрям методології наукового пізнання, підгрунтям якого є дослідження об'єктів як цілісної системи. Системним пізнанням передбачилося визначення складу, структури організації елементів; виявлення зовнішніх зв'язків системи та ii ролі серед інших; проводився аналіз діалектики структури та функцій системи; визначалися закономірності та тенденції розвитку освітньої системи за життєвим циклом [18].

Складність цієї проблеми пояснюється багатоаспектністю самої системи вищої освіти (численні зв'язки і параметри, елемент довільного реагування на зовнішні збурення), невизначеністю умов їхнього функціонування (поведінка оточення) і труднощами класифікації цілей, яких має досягти система (велика кількість критеріїв - об'єктивна властивість складної системи).

3 аналізу методів синтезу систем випливає висновок про їхній частковий характер, про спроби вирішити завдання за окремими напрямками. Наприклад, теорія статистичних рішень, враховуючи невизначеність умов, грунтується на скалярному критерії, який має суб'єктивний характер. Метод районування Дінера, позбавлений суб'єктивізму, також працює з одним критерієм і потребує в лаконічній формі зв'язку результату 3 умовами функціонування систем. Численні методи векторної оптимізації не враховують визначеності умов i мають істотні обмеження щодо виду критерію (вимоги адитивності) [3]. Це означає, що існує гостра проблема, яка полягає в потребі розроблення принципово нового підходу до оптимізації (синтезу) систем, що не мають перелічених вище недоліків.

Проблема стійкості - найбільш кардинальна проблема систем, бо вона пов'язана 3 їхнім існуванням. 3 точки зору філософії стійкість пов'язана із ступенем системи, тобто з єдністю якісних і кількісних характеристик, які не дають їй змоги за всіх кількісних змін переходити межу якісної визначеності. 
Нові завдання проектування новітніх освітніх моделей не тільки дають простір новому баченню відомих властивостей, а й вимагають нового підходу. Виходячи з викладеного вище, встановимо зв'язок між критерієм стійкості і методологією проектування новітніх освітніх систем. Розвиток поняття стійкості було зумовлено розширенням сфери дій системного підходу. Прогрес систем супроводжувався зростанням їхньої поліфункціональності. Це знайшло відображення в смисловому наповненні поняття стійкості. Застосуємо діалектичний закон розвитку по спіралі (“заперечення”). Стійкість системи у запропонованому нами змісті використовує "прямолінійну" траєкторію поведінки системи: до системи висувають певні вимоги. Якщо вона не здатна виконувати їх, іiі визнають нестійкою. Спробуємо диференційовано підійти до зовнішніх умов, які спричинюють нестійку роботу системи. Виділимо з цих умов стійку складову і визначимо можливість такої зміни системи, яка забезпечить виконання заданих вимог у розширеному діапазоні умов [15]. Це означає, що наступним етапом розвитку принципу стійкості може бути поняття динамічної стійкості: коригування, розвиток системи, що зумовить іiї якісне, стійке функціонування в умовах середовища, що змінюється. Зміна системи як спосіб збереження стійкості вимагає деталізації самого поняття "стійкість".

Система є статично стійкою, якщо іiі протидія збуренням відбувається внаслідок обмеження через випадковості. Така стійкість $\epsilon$ наслідковою, запрограмованою тільки минулим системи. На противагу статичній, динамічна стійкість досягається самоуправлінням системи за принципом зворотного зв'язку. Очевидно, що саме динамічна стійкість відповідає раціональній організації справи i взагалі сучасному інтегративному цивілізованому суспільству. У динамічно стійкій системі взаємодіють дві течії: реформаторська і консервативна. У суспільстві це досягається поділом на функції адаптації $\mathrm{i}$ стабільності особистостей. У складній системі реконструктивні і стабілізуючі функції мають перебувати в динамічній єдності. Це означає, по-перше, що система повинна не тільки бути готовою до критики стану справ, а й заоохочувати, ініціювати цю критику, бо вона сприяє розвитку освіти. Подруге, особи (можливо, навіть підрозділи), що формують своє ставлення до справ і перспектив освіти, повинні враховувати головну вимогу до критики: вона має бути конструктивною.

Неперервне виникнення і розв'язання суперечностей між стійкістю i зміною закладено у самому функціонуванні системи. Складніше дати конкретну відповідь, оскільки для цього потрібно знайти (хоча б у першому наближенні) критерій, який був би звичайним розвитком поняття стійкості. Тому стійкість функціонування системи вищої освіти доповнимо (не замінемо) стійкістю їі розвитку, а далі критерій “стійкості” не змінемо, а лише розвинемо.

$\mathrm{y}$ результаті викладеного вище ми дійшли висновку, що досягнення стійкості в динамічному розвитку системи вищої освіти - завдання сьогодення. Нині основи викладеного алгоритму, складової “поліефективності" як вектора часткових критеріїв - один із критеріїв, що відповідає витратам на проектування й впровадження системи. Відомо, що природні (та й людські) 
ресурси швидко вичерпуються, і не тільки в нашій країні. Відтак принцип економії може стати провідним у системному підході до більшості систем. Це неминуче позначиться на виборі критерію оптимізації. Якщо тепер вектор критеріїв є дисциплінуючою умовою, бо аксимілізує “надійність” досягнення потрібного рівня поліефективності, то в майбутньому, можливо, кількість обмежень скоротиться до критерію економічності (у широкому розумінні слова, включаючи час та інші ресурси), а до параметрів, що оптимізуються, увійдуть інші сьогоднішні критерії [16]. Чергове збільшення кількості оптимізуючих характеристик потребує коригування підходів, однак воно, безумовно, буде підготовлено й полегшено внаслідок реалізації принципу “стійкості інтегрованої системи вищої освіти”.

Технологічні аспекти оптимізації складних систем полікритеріальність і невизначеність - змусили нас шукати спосіб органічного поєднання різнорідних вимог до системи. Це привело до розширеного тлумачення терміна “стійкість системи”. Збагачена інтерпретація стійкості дала змогу застосувати дихотомічний поділ можливих варіантів системи: нестійкі варіанти відкидають, а стійкі, після додаткового аналізу, пропонують проектантам освітніх систем, які приймають рішення. Будь-яка система має функціонувати в заданому діапазоні зовнішніх умов, відтак до поняття стійкості освітніх моделей ми включили такі складові, як їхню надійність, мобільність, живучість, ступеневість. Цим було зроблено крок в інтерпретації стійкості - від часткового (статичного) стану до більш загального (функціонального) аспекту. Освітня модель - це система, яка створюється для досягнення заданих цілей (система оптимальних дій) i зорієнтована на оптимальний результат (оптимальне проектне рішення), а синергетичний підхід у проектуванні постає певним концептуальним базисом як сукупність певних принципових вихідних положень синергетики, згідно яких проводиться теоретичний аналіз освітніх систем [8].

Таким чином, під проектуванням освітніх моделей будемо розуміти креативно-аналітичний системний процес відтворення досліджуваної діяльності, критерієм істинності якого є стабільність існування та розвиток освітньої системи за життєвим циклом зі збереженням його характерних складових, яким визначається алгоритм системного проектування та іï функціональна спрямованість. Як вважає О.А. Грішнова, застосування досягнень у розробці синергетичної парадигми дає змогу прослідкувати всезагальність синергетичних законів, яким підкоряються процеси в системах різного онтологічного походження, що здатні до самоорганізації [5].

Подальший розвиток синергетичного підходу потребував інтерпретації основних властивостей системи під якимись декількома кутами зору. При проектуванні освітніх моделей ми намагалися використовувати для цього ефективність у широкому розумінні цього поняття. Але за межами ефективності залишалися принципово відмінні від вихідних характеристик витратні показники i ряд інших властивостей системи. Щоб усунути цю суперечність, нами було запропоновано критерій, який характеризує 
можливість виконання системою вимог, що висувають до неї у певному діапазоні умов. Цей критерій поділяє можливі ситуації на два класи: в одному 3 них система працює справно, у другому - не виконує хоча б одну із висунутих до неї вимог, а можливо, і їхню комбінацію.

3 точки зору інформаційності проектування - це процесс одержання (“виокремлення”) нової інформації 3 використанням нововведень (інновацій) [1]. 3 точки зору організаційності - це багаторівневий (ієрархічний) процес прийняття рішення. 3 точки зору процедурності - це багатоплановий процес, як процес активної творчої діяльності, що ототожнює основний чинник системи освіти - вільний розвиток індивідуальності.

Система проектування освітніх моделей - цілісна взаємозв'язна множина об'єктів, предметів (можливо однорідних); з іншого боку, система - це порядок (план, класифікація), в якій розміщується група понять для створення єдиного цілого; таким чином, система - це цілісна множина об'єктів (елементів), зв'язаних між собою взаємним відношенням, i вирішуюча завдання проектуваня. Відповідно, як справедливо вважає В.Г.Кремень, "головне завдання освіти - виявити здібності особистості. Виявлення цієї невідповідності в педагогічному процесі “бере на себе” синергетика як нова методологічна парадигма. В основі сучасних методологічних підходів, у тому числі синергетичного, до вивчення цілісного процесу соціалізації, виховання та розвитку особистості лежить загальнофілософський напрям наукового пізнання, що розкриває шляхи дослідження функціонування всього суспільства, його спільнот, окремої особистості в конкретних історико-культурних умовах" [цит. за 10].

Таким чином, проектна процедура - упорядкована сукупність взаємозв'язаних визначеними відношеннями дій, направлених на рішення завдань проектування освітніх моделей. Враховуючи парадигму сучасної освітньої системи їі імовірнісний розвиток може бути подано на основі дисипативних структур, що мають властивості нелінійності, тобто характеризуються багатоваріантністю і непередбачуваністю переходу системи 3 одного стану в іншій, тобто флуктуаційністю і відкритістю для розвитку.

У вище викладеному і загальному вигляді представлені основні ідеї, на які, в методологічному плані, ми орієнтувалися при розкритті суті теми. Вся справа в тому, що спираючись на загальну теорію систем, можна зробити далеко йдучі заключення виходячи із таких чітко сформульованих тенденцій, наприклад, перед тим як перейти до практичного здійснення своїх замислів людина створює образ реальної ситуації в своїй уяві.

Синергетичне моделювання для аналізу розвитку та трансформації освітніх систем фактично реалізує викладену схему: будується модель, яка $\epsilon$ образом реальної (майбутньої) ситуації; застосування метематичних методів моделювання й оптимізації дозволяє здійснити оптимальну математичну реалізацію (побудувати освітню систему, а застосування виробляючих систем iii фізичну (педагогічну реалізацію) [2]. Ситуація, що склалася у системі вищої освіті описується термінами синергетики, оскільки вона має біфуркаційні 
(критичні) за життєвим циклом процеси руйнування старих структур i виникнення низки тенденцій для переходу системи в нову якість. Організаційною основою забезпечення процесів проектування і прогнозування перспективних освітніх систем, якості проектних рішень $є$ логічна схема взаємодії рівнів прийняття рішень. Їх можна подати такою формулою системного аналізу: об'єкт як цільова категорія> --> <процес як категорія засобів досягнення мети $>$--> <система, яка реалізує процес>. Над всіма цими процесами домінує загальна ідея управління, структуру якої представимо формулою: <знає> <--> <може> <--> <хоче> <--> <встигає>.

Для програмування розвитку освітньої моделі потрібна здатність передбачувати послідовність дій і створювати плани, які по суті своїй повинні являтися скоріше випереджувальними, чим направляючими. Застосовуючи синергетичний підхід, який має велику теоретико-методологічну значущість, оскільки синергетика спрямовує увагу не на існуюче, а на виникаюче, а в нашому випадку організувати - означає задати упорядковану структуру, поєднати іï частини таким чином, щоб вона працювала як єдине ціле, тобто побудувати таку освітню систему, яка б вирішувала стратегічні завдання освіти суспільства. Проектування освітньої системи включає в себе визначення ii цілей, а також динаміку функціонування, а управління - як контроль виконання проектних рішень, так і планування змін, що ототожнює термін “біфуркація” як джерело розгалуження, коли відкриваються можливі шляхи розвитку освітньої системи. Проектування системи вищої освіти можна подати такою формулою системного аналізу: <наукові дослідження в галузі вищої освіти> -- <розробка інтегрованої системи та їі ресурсних забезпечень> -- <впровадження системи> - <функціонування> -- <оцінка ефективності> -- <формування і реалізація відповідних заходів коригування системи>. Під програмуванням ЖЦ системи вищої освіти у ми розуміємо процес впровадження необхідних (заданих) цільових державних освітніх стандартів у закладах вищої освіти шляхом оптимального розподілу ресурсів на всіх етапах ЖЦ, досягнення соціальноекономічної ефективності системи і процесів ЖЦ. Згідно з цільовим аспектом, програмування ЖЦ системи вищої освіти - це процес оптимального проектування й управління підготовкою фахівців за системними критеріями проблемної орієнтації (аналіз термінів навчання, кадрового, матеріальнотехнічного, інформаційно-методичного забезпечення), їхньої ефективності.

На основі аналізу вітчизняної та зарубіжної практики проектування освітніх систем ми узагальнили процедурне програмування ЖЦ системи вищої освіти, яка $\epsilon$ комплексно-цільовою процедурою, завдяки якій на єдиній інформаційній, педагогічній і методологічній основі забезпечується єдність вимог до змісту та якості підготовки фахівців, незалежно від відомчої підпорядкованості закладів вищої освіти та форм власності.

Висновки та перспективи подальших досліджень. Практика трансформаційних змін моделей вищої освіти у різних країнах світу протягом останніх десятиліть є неоціненним матеріалом для аналізу, з якого не завадило б зробити певні висновки. Найголовніші з них такі: а) реформування освіти - 
глобальний процес, а відтак для його здійснення вкрай потрібно досягти консенсусу, згоди на зміни всіх учасників (від школярів та їхніх сімей до політиків найвищого рангу). Одне із завдань управління системою освіти прикласти зусилля по створенню й підтриманню такого консенсусу; б) значних успіхів у поліпшенні й розширенні всіх рівнів власних моделей вищої освіти досягли лише ті країни, в яких підвищення валового національного продукту супроводжувалося зростанням рівня освіти та створенні суспільного клімату прагнення й поваги до знань і наявності систем законів для інтенсифікації цього прагнення; в) впровадження реформ національної моделі вищої освіти, щодо практичної реалізації синергетичного підходу у підготовці конкурентоздатного фахівця, передбачає не одночасність змін усіх i всього, а вироблення науковцями реальної послідовності заходів щодо поступового створення єдиного Європейського освітнього простору без катаклізмів i надмірних прискорень; г) жодна країна з розвиненою системою закладів вищої освіти не досягне іï успішної й повної трансформації, якщо задовольнятиметься лише кількісним збільшенням пропозицій на ринку освітніх послуг; д) розумне управління 3 центру змінами в освіті не менш важливе, а ніж наявність необхідних фінансових і кадрових ресурсів. Втім, завдання центру полягає не у створенні примітивної системи постанов, наказів, правил і програм, а в організації сучасної системи моніторингу за станом освіти, оцінюванням компетентностей. Без даних про такий зворотний зв'язок малі негаразди швидко зростатимуть, корелюватимуть негативно, i повернення на правильну траєкторію руху буде запізним і потребуватиме значних затрат коштів; е) недержавний сектор закладів вищої освіти може гармонійно доповнити державний, бо він гарантує соціальну рівність в доступі до освіти. Додержання ж необхідного рівня соціальної справедливості - одне 3 найважливіших політичних завдань управління системою освіти; є) серед завдань, які ставлять перед собою розвинені країни, є забезпечення якості життя свого населення. Для досягнення цієї мети необхідно реалізувати безліч заходів, здійснити чимало перетворень, трансформуючи їх у новітню концепцією реформування й черговості вирішення освітянських завдань, що їх визначають окремі країни i людство в цілому. Цей зовнішній чинник 3 кожним роком дедалі сильніше впливає як на внутрішню, так i на зовнішню політику реформування недержавного сектору в національній і міжнародних моделях вищої освіти.

Таким чином, визначивши зовнішні та внутрішні проблеми вищої освіти на сучасному етапі, до яких слід віднести ринкові відносини у вищій освіті, які спрямовані на зміну характеру, місця та ролі недержавного сектору освіти у суспільстві, недосконалість реформ у сфері вищої освіти та відсутність відповідної законодавчої бази, що створює перешкоди для інтеграції національної системи вищої освіти в Європейський освітній простір, необхідно продовжувати перспективні дослідження українських учених щодо аналізу трансформаційних процесів, які відбуваються в недержавному секторі національної систем вищої освіти. 


\section{ЛІТЕРАТУРА}

1. Андрос Є.I. Проблема свободи у контексті раціоналізації людського буття // Людина в цивілізації XXI століття: проблема свободи. К. : наук. думка, 2005. С. 127-174.

2. Андрущенко В. Освіта в пошуках нових стратегій мислення // Вища освіта України. 2003. - № 2. - C.5-6.

3. Дубасенюк О.А. Упровадження освітніх інновацій в системі вищої освіти //Інновації у вищій освіті: проблеми, досвід, перспективи: монографія /за ред. П.Ю. Сауха. Житомир : Вид-во ЖДУ ім. Івана Франка, 2011. - 444 с.

4. Гриневич Л. План демонополізації освіти і науки. URL : http://educationua.org/ua/articles/218 plan-demonopolizatsiji-osviti-i-nauki.

5. Грішнова О.А. Людський, інтелектуальний і соціальний капітал України: сутність, взаємозв'язок, оцінка, напрями розвитку // Соціально-трудові відносини : теорія та практика. Збірник наук. праць. №1 (7)/2014. С. 34-42.

6. Свтодюк А.В. Аксіологічні засади сучасної системи освіти України // Педагогічний пошук. - 2014. - № 2. - C. 12-15 URL: http://nbuv.gov.ua/UJRN/pedp_2014_2_5

7. Катеринчук О.В. Модернізація системи освіти. - К. : Пед. думка, 2012. URL : http://intkonf. org/katerinchuk-ovmodernizatsiya-sistemi-osviti/

8. Князева Е.Н., Курдюмов С.П. Основания синергетики. Режимы с обострением, самоорганизация, темпомиры /Е.Н. Князева, С.П. Курдюмов. - СПб. : Алтейя, 2002. - 414.

9. Концептуально-методологічні основи проектування методів і засобів діагностики освітніх результатів у вищих навчальних закладах: монографія /за заг ред. В.І.Лугового, О.Г. Ярошенко. - К. : Пед. думка, 2014. - 234 с.3.

10. Кремень В.Г. Філософія національної ідеї. Людина. Освіта. Соціум. - К. : Грамота, 2007. $-576 \mathrm{c}$.

11. Лігоцький А.О. Теоретичні основи проектування сучасних освітніх систем. /Монографія - К.: Техніка, 1996. - 210 с.

12. Огнев'юк В.О., Сисоєва С.О. Освітологія - науковий напрям інтегрованого дослідження ЧАСТИНА І. Методологічні засади освітології сфери освіти / В. О. Огнев'юк, С. О. Сисоєва //Рідна школа. - 2012. - № 4 - 5. - С. 44.

13. Освітні реформи: місія, дійсність, рефлексія: моногр. /за ред. Василя Кременя, Тадеуша Левовицького, Віктора Огнев”юка, Світлани Сисоєвої. - К. : ТОВ Видавниче підприємство "Едельвейс", 2013. - 460 с.

14. Allen, J., \& van der Velden, R. (Eds.). (2011). The flexible professional in the knowledge society: New challenges for higher education. Dordrecht: Springer.

15. Altbach, P.G., Reisberg, L., \& Rumbley, L.A. (2009). Trends in global higher education: Tracking an academic revolution. Paris: UNESCO.

16. Horta, H., \& Jung, J. (2013). Higher education research in Asia: An archipelago, two continents or merely atomization? Higher Education in Europe, 68 (1), 117-134.

17. Modernization and employability at heart of new higher education reform strategy. URL: http://www.europe.eu.

18. Pasternack, P. (Ed.). (2014). Hochschulforschung von innen und seitwärts: Sichtachsen durch ein Forschungsfeld (Higher education from within and from aside: Perspectives through an research field). Wittenberg: Institut für Hochschulforschung (die hochschule. Journal für wissenschaft und bildung, 1/2014).

\section{REFERENCES}

1. Andros, Ye.I. (2005). Problema svobody u konteksti ratsionalizatsii liudskoho buttia [The problem of freedom in the context of rationalization of human existence]. Liudyna $\mathrm{v}$ tsyvilizatsii XXI stolittia: problema svobody - Man in the 21st century civilization: the problem of freedom. (pp. 127-174). Kyiv: Nauk. dumka (in Ukrainian). 
2. Andrushchenko, V. (2003). Osvita v poshukakh novykh stratehii myslennia [Education in search of new thinking strategies]. Vyshcha osvita Ukrainy - Higher Education in Ukraine, 2, 5-6 (in Ukrainian).

3. Dubaseniuk, O.A. (2011). Uprovadzhennia osvitnikh innovatsii v systemi vyshchoi osvity [Implementation of educational innovations in the higher education system]. P. Yu. Saukh (Eds.). Innovatsii u vyshchii osviti: problemy, dosvid, perspektyvy - Innovations in higher education: problems, experience, prospects. Zhytomyr: Vyd-vo ZhDU im. Ivana Franka (in Ukrainian).

4. Hrishnova, O.A. (2014). Liudskyi, intelektualnyi i sotsialnyi kapital Ukrainy: sutnist, vzaiemozviazok, otsinka, napriamy rozvytku [Human, intellectual and social capital of Ukraine: essence, interconnection, assessment, directions of development]. Sotsialno-trudovi vidnosyny: teoriia ta praktyka - Social-labor relations: theory and practice, 1(7), 34-42 (in Ukrainian).

5. Yevtodiuk, A.V. (2014). Aksiolohichni zasady suchasnoi systemy osvity Ukrainy [Axiological bases of the modern system of education in Ukraine]. Pedahohichnyi poshuk Pedagogical search, 2, 12-15. URL http://nbuv.gov.ua/UJRN/pedp_2014_2_5 (in Ukrainian).

6. Katerynchuk, O.V. (2012). Modernizatsiia systemy osvity [Modernization of the education system]. Kyiv: Ped. Dumka. URL http://intkonf.org/katerinchuk-ovmodernizatsiya-sistemi-osviti/ (in Ukrainian).

7. Knyazeva, E.N., Kurdyumov, S.P. (2002). Osnovaniya sinergetiki. Rezhimy s obostreniem, samoorganizatsiya, tempomiry [Foundations of synergetics. Modes with exacerbation, selforganization, tempo-worlds]. Saint Petersburg: Alteyya (in Russian).

8. Kremen, V.H. (2007). Filosofiia natsionalnoi idei. Liudyna. Osvita. Sotsium [Philosophy of the national idea. Man. Education. Socium]. Kyiv: Hramota (in Ukrainian).

9. Kremen, V., Levovytskyi, T., Ohnevyuk, V., Sysoieva, S. (Eds.). (2013). Osvitni reformy: misiia, diisnist, refleksiia [Educational reforms: mission, reality, reflection]. Kyiv: TOV Vydavnyche pidpryiemstvo "Edelveis" (in Ukrainian).

10. Lihotskyi, A.O. (1996). Teoretychni osnovy proektuvannia suchasnykh osvitnikh system [Theoretical bases of modern education systems design]. Kyiv: Tekhnika (in Ukrainian).

11. Luhovyi, V.I., Yaroshenko, O.H. (Eds.). (2014). Kontseptualno-metodolohichni osnovy proektuvannia metodiv i zasobiv diahnostyky osvitnikh rezultativ u vyshchykh navchalnykh zakladakh [Conceptual and methodological bases for designing methods and means of diagnostics of educational results in higher education institutions]. Kyiv: Ped. dumka (in Ukrainian).

12. Ohneviuk, V.O., Sysoieva, S.O. (2012). Osvitolohiia - naukovyi napriam intehrovanoho doslidzhennia. Chastyna I. Metodolohichni zasady osvitolohii sfery osvity [Education - Scientific direction of the integrated study. Part I. Methodological principles of education in the sphere of education]. Ridna shkola - Native school, 4-5, 44-51 (in Ukrainian).

13. Plan demonopolizatsii osvity i nauky vid Lilii Hrynevych [The education and science demonopolization plan by Liliia Hrynevych]. (n.d.). education-ua.orh. URL http://educationua.orh/ua/articles/218plan-demonopolizatsiii-osviti-i-nauki (in Ukrainian).

14. Allen, J., \& van der Velden, R. (Eds.). (2011). The flexible professional in the knowledge society: New challenges for higher education. Dordrecht: Springer (in English).

15. Altbach, P.G., Reisberg, L., \& Rumbley, L.A. (2009). Trends in global higher education: Tracking an academic revolution. Paris: UNESCO (in English).

16. Horta, H., \& Jung, J. (2013). Higher education research in Asia: An archipelago, two continents or merely atomization? Higher Education in Europe, 68(1), 117-134 (in English).

17. Modernization and employability at heart of new higher education reform strategy. (2018). www.europe.eu. URL http://europa.eu/rapid/press-release_IP-11-1043_en.htm (in English).

18. Pasternack, P. (Ed.). (2014). Hochschulforschung von innen und seitwärts: Sichtachsen durch ein Forschungsfeld. Die Hochschule. Journal für wissenschaft und bildung, 1, 63-75 (in German).

\section{PЕЗЮМЕ}

Анатолий Лигоцкий, доктор педагогических наук, профессор 


\section{Феноменология проектирования новейших образовательных систем в глобальной образовательной среде}

В статье исследуется проблема кониептуализащии когнитивно-коммуникативных $и$ информационно-семиотических измерений проектирования инновационной модели высшего образования на мировом и отечественном уровне в научном дискурсе XXI века. Обосновываются актуальность исследуемой проблемы, методологические основы проектирования новейших образовательных систем на основе синергетического подхода в качестве способа анализа педагогических явлений; рассмотрены инновачионные подходы к проектированию образовательных моделей в контексте понимания креативноаналитического системного проиесса воспроизводства исследуемой деятельности.

Ключевые слова: проектирование; синергетический подход; образовательные модели; высшее образование.

\section{SUMMARY}

Anatoliy Ligotskiy, Doctor of pedagogical Science, Professor

\section{Phenomenology of the design of new educational systems in the globals educational environment}

Introduction. It is taken as a benchmark that every person is interested in the fact that not only the widest possible reveal his dignity and potential opportunities, not only to receive education, but also the ability to adapt to the new political and socio-economic realities of the present. The state, however, should take care of the satisfaction of these needs of the individual, which would be combined with the examination of the needs of the community as a whole. To do this, it is necessary to rely on the theoretical model of the "innovative person", which is tested in the world and focused on instilling proficiency, solid knowledge, flexibility and mobility into high school graduates.

Purpose. The purpose of the article is the theoretical substantiation of the algorithm of system design of the model of the modern educational system, which reveals the essence and features of the global educational environment.

Methods. The system of general scientific and special methods of theoretical (analysis of scientific literature on the studied problem, systematization, generalization of materials, content analysis) and empirical research (monitoring of military specialists, use of diagnostic tools, etc.).

Results. On the basis of the analysis of domestic and foreign practice in the design of educational systems, we generalized the procedural programming of the JC system of higher education, which is a complex and objective procedure, through which a unified information, pedagogical and methodological basis ensures the unity of requirements to the content and quality of training of specialists, regardless of departmental subordination institutions of higher education and forms of ownership.

Originality. The organizational framework for ensuring the processes of designing and forecasting of perspective educational systems, the quality of design decisions is a logical scheme of interaction of decision-making levels. They can be submitted using the following system analysis formula: object as target category - process as a category of means to achieve the goal - system that implements the process.

Conclusion. The priority of the directions of the state policy in the context of the integration of the national higher education into the European and world educational space is that the necessary prerequisite for the design of an innovative model of higher education is the coherent renewal of the educational system, in particular, the improvement of its staffing, which to a large extent depends on the ability of the education system to train highly skilled professionals.

Key words: design; synergetic approach; educational models; higher education. 